Lee JR, Phillips E. 2008. Progressive soft sediment deformatio within a subglacial shear zone - a hybrid mosaic-pervasive deformation model for Middle Pleistocene glaciotectonised sediments from Eastern England. Quaternary Science Reviews, 27: 1350-1362.

\title{
Progressive soft sediment deformation within a subglacial shear zone - a hybrid mosaic-pervasive deformation model for Middle Pleistocene glaciotectonised sediments from Eastern England
}

\author{
Jonathan R. Lee ${ }^{1^{*}}$ and Emrys R. Phillips ${ }^{2}$ \\ ${ }^{1 B}$ British Geological Survey, Keyworth, Nottingham, NG12 5GG, UK. \\ ${ }^{2}$ British Geological Survey, Murchison House, West Mains Road, Edinburgh, EH9 3LA, UK. \\ * Corresponding Author: J R Lee (email: jrlee@bgs.ac.uk)
}

\begin{abstract}
This paper presents a hybrid 'pervasive' and 'mosaic' model for the progressive deformation of a stratified diamicton complex in eastern England within an active subglacial shear zone. Sedimentary evidence from undeformed low strain zones towards the base of the sediment pile indicate that the tectonised sediments were originally deposited as a series of subaqueous flows in a glaciolacustrine basin. These sediments have subsequently been deformed during a progressive subglacial shearing event. This event is divided into three stages: ductile folding and sediment remobilisation (D1), brittle faulting in the form of Reidel shears (D2); and hydrofracturing and sediment remobilisation (D3). The dominant control on the pattern and style of deformation appears to relate to the rate of thrust-induced till accretion, and the aquifer properties and pore water content and / or pressure of the deforming sediments.
\end{abstract}

\section{Introduction}

The introduction of a 'soft deforming bed' model to explain the movement and transport of sediment beneath glaciers and ice sheets has revolutionised the fields of glaciology and glacial geology over the past 30 years (Boulton, 1986; Boulton and Hindmarsh, 1987). Considerable research has focussed upon the examination of evidence for the roles played by subglacial deforming beds in controlling the dynamics of the major Pleistocene ice sheets of North America and northern Europe (Boulton and Jones, 1979; Licciardi et al., 1998; Piotrowski et al., 2001). This has led to the assertion that the dynamics of these large continental-scale ice sheets may in-part be driven, and in-turn be drivers of past climate change via a series of complex feedback mechanisms that operate between terrestrial, oceanic and atmospheric systems (Broecker et al., 1992; Clark, 1994; Hughes, 1996; Clark et al., 1999). It has also been suggested that deformable beds exist beneath several contemporary ice masses including the West Antarctic Ice Sheet (Alley et al., 1987; Evans et al., 2006), and the melting of these ice sheets could exert a major influence on future climate and sealevel changes (Hughes, 1996; Bentley, 1997). An understanding of the nature and processes operating within subglacial deforming beds is therefore of critical importance. 
Lee JR, Phillips E. 2008. Progressive soft sediment deformatio within a subglacial shear zone - a hybrid mosaic-pervasive deformation model for Middle Pleistocene glaciotectonised sediments from Eastern England. Quaternary Science Reviews, 27: 1350-1362.

Recent research on modern ice sheets has shown that rates of basal ice flow, even where ice is overriding deforming subglacial beds that typically encourages faster ice flow, can vary both temporally and spatially (Alley, 1993). Such basal flow behaviour is referred to as 'stick-slip basal ice flow' where subglacial variations in pore water content and / or pressure, subglacial shear stress, drag and ice velocity at the ice-bedinterface (IBI) create zones of basal 'stick' (or 'stable' beds) and 'slip' (or 'deforming' beds) (Fischer and Clarke, 1997; Hooke et al., 1997; Fischer et al., 1999). Evidence for 'stick-slip basal ice flow' has been recognised within the geological record, suggesting that the subglacial bed is in reality a 'mosaic' composed of zones of 'stable' and 'deforming' beds that change configuration in time and space (Piotrowski and Kraus, 1997; Piotrowski et al., 2004; Evans et al., 2006). Geological evidence from Pleistocene tills support theories proposed for the mechanics of 'stickslip basal flow' inferred from contemporary ice sheets in that water-induced decoupling at the IBI (Hoffman and Piotrowski, 2001; Knight, 2002; Iverson et al., 2003) and zones of different permeability within the subglacial bed (Piotrowski et al., 2004; Evans et al., 2006) are the primary drivers. This contrasts with the views of van der Meer (2002) and Menzies et al. (2006), who argue that subglacial deformation is pervasive and overprints till facies accreted under different basal flow regimes (e.g. lodgement or melt-out) such that all subglacial tills are deformation tills ('tectomict' of Menzies et al., 2006). In this paper, we contribute to this argument by examining the structural evolution of a Middle Pleistocene subglacial shear zone in northern East Anglia, UK. The variation in intensity of deformation recorded by these sediments reveals a complex pattern of 'higher strain' and 'lower strain' domains, and these relate these to changes in inter-granular pore water content driven by lithology and subglacial till accretion.

\section{Location and Geological Context}

The location of the study site for this investigation is Bacton Green (National Grid Reference TG 338345), situated on the east coast of England (Fig.1). Sections at Bacton Green consist of low coastal cliffs rising to a maximum observed height of $16 \mathrm{~m}$ above the level of the foreshore.

The region lies adjacent to the southern North Sea Basin and the pattern and chronology of lowland glaciation is currently the subject of considerable debate (Hamblin et al., 2000, 2005; Banham et al., 2001). Previously, the region was considered to have been glaciated only once during the Middle Pleistocene. This glaciation occurred during Marine Isotope Stage (MIS) 12 and deposited thick accumulations of till and outwash sediments by apparently coalescing British and Scandinavian ice sheets (Perrin et al., 1979; Bowen et al., 1986; Ehlers and Gibbard, 1991; Bowen, 1999). More recently, the development and application of a new stratigraphy for the glacial deposits of the region (Lee et al., 2004a; Hamblin et al., 2005), has led to the validity of this single glaciation model being questioned. Instead it has been suggested that some of the glacial deposits previously assigned to MIS 12 
Lee JR, Phillips E. 2008. Progressive soft sediment deformatio within a subglacial shear zone - a hybrid mosaic-pervasive deformation model for Middle Pleistocene glaciotectonised sediments from Eastern England. Quaternary Science Reviews, 27: 1350-1362.

may correspond to earlier and later Middle Pleistocene glaciations (Hamblin et al., 2000, 2005; Lee et al., 2004b; Clark et al., 2004) although this view is not accepted by all (see Banham et al., 2001; Gibbard et al., 2008 and responses by Hamblin et al., 2001 and Lee et al., 2008). Furthermore, lithological evidence does not support the theory that elements of this glacial sequence, the North Sea Drift (Cromer Tills), were deposited by the Scandinavian Ice Sheet as proposed in the earlier model of glaciation (Lee et al., 2002, 2004a). Instead, the presence of low-durability lithologies (e.g. Permian limestone, Carboniferous coal and limestone) from northern Britain demonstrates that these tills were transported and deposited by a British Ice Sheet (Lee et al., 2002). Large- and small-scale structures within the glacial deposits of northern East Anglia have also been studied extensively and this has contributed significantly to both an understanding of the glacial evolution of the region, and wider concepts of glaciotectonic processes (Slater, 1926; Banham, 1975; Hart, 1990; Hart \& Boulton, 1991; Hart \& Roberts, 1994; Roberts \& Hart, 2005).

The site of Bacton Green encompasses stratigraphic elements previously assigned to the Scandinavian North Sea Drift (Lunkka, 1994); however these elements have now been reclassified as a result of a recent mapping-based stratigraphic investigation (Lee et al., 2004a). The stratigraphy of the site consists of two tills, separated and overlain by outwash (Lunkka, 1994; Lee, 2003). The lower till is a massive grey chalky diamicton and corresponds to the Walcott Till Member (formerly Second Cromer Till) of the Lowestoft Formation. The till is overlain by two members of the Sheringham Cliffs Formation: a $12 \mathrm{~m}$ thick fluvio-deltaic glacial outwash sand called the Mundesley Sand Member (MSM), which in-turn is overlain by a stratified till sequence, some $14 \mathrm{~m}$ thick, called the Bacton Green Till Member (BGTM) (Lee, 2003). This upper till is truncated by glaciofluvial outwash gravels called the Stow Hill Sand and Gravel Member (Britons Lane Formation) (Fig.2).

\section{Methodology}

The depositional setting and subsequent deformation history of the Bacton Green Till Member has been investigated using a range of macro- and micro-scale techniques. Sections were logged and described on the basis of their macro-scale features with particular emphasis placed on recording the type of bedding, sediment texture, structure (both sedimentary and tectonic), sediment colour (Munsell), and bed geometry. In addition, a total of eight samples of unconsolidated sand and diamicton material were collected from the stratified diamicton complex in order to examine some of the macro-scale features in thin section. Four samples are described here including $\mathrm{BG} 4 / \mathrm{E}$ and $\mathrm{BG} 4 / \mathrm{F}$, taken from an elongate lens of diamicton located towards the centre of the exposed section, and BG4/A and BG4/C which were collected from different structural levels within the surrounding inter-layered sand and diamicton.

Orientated undisturbed samples were cut from the cliff sections within aluminium Kubiena tins, dried by a mixture of air-drying and acetone replacement, 
Lee JR, Phillips E. 2008. Progressive soft sediment deformatio within a subglacial shear zone - a hybrid mosaic-pervasive deformation model for Middle Pleistocene glaciotectonised sediments from Eastern England. Quaternary Science Reviews, 27: 1350-1362.

impregnated with a polyester resin and cut and polished into thin sections following standard procedures (Lee and Carr, 1998) within the Thin Section Laboratory, Department of Geography, Royal Holloway, University of London. Thin sections were examined using a standard petrological microscope and Zeiss projector enabling the analysis of both large and small-scale microscopic textures and fabrics, and these were described following standard nomenclature (van der Meer, 1993; Carr, 1998; Menzies, 2000). Annotated scanned images of each thin section have been used to describe the main microscopic features.

\section{Description and Interpretation of the stratified diamicton complex}

Evidence of glaciotectonic deformation within the BGTM varies in occurrence and nature spatially (Fig. 2). The basal $7 \mathrm{~m}$ of the till forms a highly heterogeneous 'lower facies' containing areas of minimal glaciotectonic disturbance, in which the original depositional character of the sediments can still be recognised, separated by a network of more highly deformed zones in which the primary sedimentary structures have been overprinted. By contrast, the upper $7 \mathrm{~m}$ of the till form an 'upper mélange facies' composed of folded, faulted and fractured beds of sand and diamicton. For ease of description and interpretation the range of depositional and deformation features present within the complex till at Bacton Green are divided into three sections - 'sedimentology', 'macro-scale deformation structures' and 'micromorphology'.

\subsection{Sedimentology}

The base of the BGTM is exposed one hundred and fifty metres northwest of the main study area, exposing beneath it, a thick sequence of stratified silty sand (MSM). The contact between the two units is often gradational over a vertical aspect of 0.8-1.2 $\mathrm{m}$ comprising alternate and intercalated beds of diamicton and rippled sand. Elsewhere, the contact between the two units is sharp and planar, with convolute bedding and flame structures well-developed within the upper horizons of the underlying sand.

The basal $7 \mathrm{~m}$ ('lower facies') of the BGTM, comprises layers of massive to weakly laminated diamicton, separated by horizons of thinly-bedded to laminated silty sand and sand. Beds of diamicton are highly consolidated and matrixsupported, dark olive-brown (2.5Y 3/3) to dark grey (5Y 4/1) in colour, and contain scattered clasts of flint, vein quartz and shell debris. Although typically massive, the diamictons occasionally contain thin horizontal stringers of normally-graded sand leading to a variably developed stratification. The intervening sand units range from $<1 \mathrm{~cm}$ thick sand laminae to much thicker (0.1-0.4 m thick) units of silty sand and poorly sorted clayey sand which can be traced laterally for several tens of metres into zones of deformation. The lower boundaries of these sands, with the underlying diamicton, are typically sharp and flat lying. Rare, small rounded intraclasts of diamicton (rip-up clasts) occur within the sand immediately above this junction. 
Lee JR, Phillips E. 2008. Progressive soft sediment deformatio within a subglacial shear zone - a hybrid mosaic-pervasive deformation model for Middle Pleistocene glaciotectonised sediments from Eastern England. Quaternary Science Reviews, 27: 1350-1362.

Individual beds or laminae of sand may be massive or exhibit either normal or reversed grading.

The upper $7 \mathrm{~m}$ ('upper mélange facies') of the BGTM consists of a contorted mélange of diamicton (lithologically identical to that described above) with thin disrupted beds of sand and large lenses or pods of sand and sandy gravel. The highly deformed nature of this mélange means that primary sedimentary features are either very poorly preserved or absent.

The preservation of primary sedimentary structures within the least deformed parts of the BGTM point to a sedimentary rather than glaciotectonic genesis for the diamicton complex. Highly consolidated and massive beds of diamicton are typical of materials mixed together and homogenised subglacially. The thin sandy stringers present within the beds of diamicton could be interpreted as lenses of sand incorporated locally and progressively attenuated during shearing (Hart and Roberts, 1994; McCarroll and Rijsdijk, 2003). However, the presence of graded bedding implies that these lenses are sedimentary rather tectonic in origin. A possible mechanism being the remobilisation and subsequent resettling of material by subaqueous traction currents (Eyles and Eyles, 1983). Such a mechanism would imply that the beds of diamicton, although originally deposited as subglacial till, were subsequently reworked as cohesive, subaqueous mass flows. Lending support to this theory is the geometry and nature of the boundary between the BGTM and underlying MSM where features diagnostic of subglacial deformation such as décollement surfaces, low-angle thrusts and folding are absent. Instead, the geometry of the boundary is more typical of a subaqueous style of sedimentation with alternate and intercalated beds of diamicton and sand reflecting pulses of diamicton being introduced into a standing body of water (Eyles et al., 1985; Hart and Roberts, 1994). Beds and laminae of silty sand and clayey sand are interpreted as being deposited from the rapid rain-out of poorly-sorted material from dense sediment-laden underflows (Eyles et al., 1989; Lee, 2001) whilst reversed and normal graded bedding relate to sedimentation from accelerating and waning turbidity flows. Small-scale scouring associated with the turbidity flows is indicated by the small intra-clasts of diamicton aligned along the base of the sandy beds.

\subsection{Macro-scale deformation structures}

The BGTM locally shows evidence of intense deformation including folding, thrusting, normal and reverse faulting, as well as hydrofracturing and water-escape.

\section{Recumbent Folds}

Beds of sand and diamicton are locally deformed by a number of tight to isoclinal folds (Fig. 3a). These recumbent to gently inclined structures are developed in the hanging walls of very gently dipping to sub-horizontal thrusts that truncate the overturned limbs of the folds. The amplitude of the folds ranges from a few tens of centimetres up to several metres, and their limbs occur parallel to the layering 
Lee JR, Phillips E. 2008. Progressive soft sediment deformatio within a subglacial shear zone - a hybrid mosaic-pervasive deformation model for Middle Pleistocene glaciotectonised sediments from Eastern England. Quaternary Science Reviews, 27: 1350-1362.

developed elsewhere within the BGTM. Smaller-scale folds may exhibit a marked asymmetry, verging towards the north or northeast. In the more intensely deformed areas the limbs of the folds are highly attenuated, thinning rapidly away from the hinge, with localised boudinage leading to fragmentation and formation of isolated rootless structures. In contrast to the attenuated limbs, sand layers within the hinges of the folds are thicker and deformed by small-scale $\mathrm{S}, \mathrm{M}$ and Z-shaped parasitic fold structures. Small-scale thrusts and gently to moderately dipping reverse faults are also present within the hinges of the folds.

The geometry of the highly attenuated to rootless recumbent folds is typical of structures developed within ductile shear zones in response to relatively high shear strains. However, the disharmonic nature of the parasitic folds associated with the larger scale structures suggests that the sediments had a high pore-water content (and/or pressure) at the time of deformation. This would have lowered the cohesive strength of the sediment pile allowing the formation of the isoclinal, locally rootless folds at much lower strains. The sense of displacement on the associated thrusts and reverse faults is towards the north. This coupled with the overall shape of the folds suggests that folding developed in response to northerly-directed shear.

\section{Normal faults and extensional shears}

At the south-eastern end of the section the BGTM is deformed by a number of gently to moderately northerly dipping normal faults and associated extensional shears (Fig. 3b). The structures record the same sense of offset with a down-throw dipping towards the north to northeast. The amount of displacement on the faults ranges from $1 \mathrm{~cm}$ to $30 \mathrm{~cm}$. Minor ductile folding and drag folding occurs immediately adjacent to the normal faults. Consequently, associated shears are thought to have developed in response to, and during an 'early' ductile phase prior to brittle faulting.

\section{Sand lenses or augen}

Symmetrical to asymmetrical eye-shaped lenses or augen of sand occur throughout both the 'lower facies' and the 'upper mélange facies' within the BGTM. The sand lenses range from $0.2 \mathrm{~m}$ to $2.0 \mathrm{~m}$ and are elongate parallel to the plane of layering within the 'lower facies' but occur as isolated sand bodies within the matrix of the 'upper mélange facies'.

Compositional layering within the 'lower facies' clearly wraps around the sand lenses (Fig. 3c) showing that they form an integral part of the sequence and were not intrusive, as they would be if they were deposited in tunnel-like features (e.g. sub-glacial channels) eroded into the till. Elongate tails which extend from the sand lenses are streaked out into the banding within the host sediments. Smaller lenses or ribbons of sand detached from these tails can be traced up to several metres away from the larger sand lenses. Sands within these lenses are well-bedded to finely-laminated with bedding being deformed by variably-developed asymmetrical, 
Lee JR, Phillips E. 2008. Progressive soft sediment deformatio within a subglacial shear zone - a hybrid mosaic-pervasive deformation model for Middle Pleistocene glaciotectonised sediments from Eastern England. Quaternary Science Reviews, 27: 1350-1362.

northerly verging folds (Fig. 3c). These folds are enclosed within a variably developed 'envelope' of massive, structureless sand in which bedding has been overprinted. The hinges of the tight, gently inclined to recumbent folds, where developed, dominate the structure of the sand lens. The limbs of the fold are clearly truncated at the margins of the augen, which implies that these features are tectonic rather than sedimentary in origin.

Frequently associated with the main fold structures are S, M and Z-shaped parasitic folds and small-scale reverse faults and thrusts. The faults are most common in the hinge area of the folds and developed to accommodate further shearing associated with the progressive tightening of these ductile structures. These smaller scale folds are locally disharmonic with flame-like projections extending from these folds and defining a crude foliation parallel to the axial plane of the larger scale fold structure. The disharmonic nature of the folds and wispy, flame-like appearance of the axial planar foliation indicate that pore water content/pressure increased during folding resulting in localised liquefaction and remobilisation of the sandy layers. The asymmetry of the folds and shape of the sand lenses is consistent with them having formed in response to the same northerly directed shearing event. The folds preserved within the sands are interpreted as representing the detached, rootless hinges of originally much larger fold structures.

Sand lenses within the 'upper mélange facies' are typically massive and lack much obvious internal structure although do exhibit convolute bedding.

Examination of the heavy mineral composition of the sand lenses, demonstrate that they are derived from the underlying MSM (Lee, 2003). This suggests that part of this laterally extensive sand body was being fragmented during the progressive shearing of the overlying BGTM.

\section{Transposed bedding}

In the 'upper mélange facies' of the BGTM, the original bedding has been strongly modified or transposed during deformation. This well-developed, laterally extensive compositional layering is defined by $1 \mathrm{~cm}$ up to $30 \mathrm{~cm}$ thick sand layers which lack any primary sedimentary features. This 'tectonic layering' wraps around the detached, rootless folds and previously described lenses/augen of sand, without any obvious signs of disturbance. Unlike the original bedding, the margins of individual sand layers are sharp and highly planar. Although some layers show a lateral variation in thickness, the majority maintain a relatively uniform thickness over several metres.

\section{Thrusts}

Beds of diamicton and sand within the 'lower facies' of the BGTM are locally cut out or off-set by a number of sub-horizontal to gently southwesterly dipping thrust faults (Fig. 3d). These thrusts record a northerly directed sense of displacement and are locally associated with previously described recumbent folds. Thrusting appears to 
Lee JR, Phillips E. 2008. Progressive soft sediment deformatio within a subglacial shear zone - a hybrid mosaic-pervasive deformation model for Middle Pleistocene glaciotectonised sediments from Eastern England. Quaternary Science Reviews, 27: 1350-1362.

have been focused within the diamicton layers, ramping upwards to truncate bedding within the adjacent sandy horizons. Thin lenses of sand locally occurring within the hanging walls of some thrusts can be traced laterally into the larger sand augen, and represent fragments detached from these rootless fold structures.

The northerly sense of displacement recorded by the thrusts is consistent with the sense of shear obtained from the previously described folds and sand augen, indicating that all of these structures developed during the same northerly directed deformation event.

\section{Kink folds and associated faults}

At the northern end of the section the sand layers within the 'lower facies' of the BGTM are deformed by a number of angular, asymmetrical kink-like folds (Figs. 3e, f). The axial surfaces of these open kink folds dip steeply towards the south. The folds verge towards the north and are associated with a set of moderately southerly dipping reverse faults. The sense of displacement on these faults is towards the north with faulting occurring within the hinge, or on the steeply inclined short limb of the folds. It is likely that faulting occurred in response to brittle failure as the earlier formed folds began to tighten. An angular box-like fold structure is apparently related to the kink-like folds and developed immediately adjacent to an augen of coarse-grained sand.

\section{Sand-filled hydrofractures}

Sand-filled hydrofractures can be recognised within the structurally higher parts of the BGTM or 'upper mélange facies'. These consist of sub-vertical to steeply dipping fractures that are filled by fine- to medium-grained sand similar in composition to the sand layers present elsewhere within the sequence. The sandy fill of these fractures suggests that they are hydrofractures formed by water-escape from a confined aquifer. As the hydrofractures cross-cut both the stratification developed within the BGTM and the large-scale recumbent fold structures, this phase of liquefaction and water-escape post-dates folding.

\subsection{Micromorphology}

In thin sections BG4/A and BG4/C (Fig. 2) the sand-rich horizons within BGTM are composed of finely laminated, poorly-sorted fine- to medium-grained sand to silty sand containing scattered coarse sand to pebble sized clasts (Fig. 4). Two specific textural types of laminae are evident. Firstly, sand laminae with a grain-supported, open texture which exhibit variations in the modal matrix content, resulting in the preservation of an inter-granular porosity. Secondly, more silty/matrix-rich laminae that exhibit a more open packing and matrix-support texture. In sample BG4/C the lamination is off-set by two, moderately inclined faults. Immediately adjacent to the faults the laminae are attenuated and have undergone minor drag folding. The 
Lee JR, Phillips E. 2008. Progressive soft sediment deformatio within a subglacial shear zone - a hybrid mosaic-pervasive deformation model for Middle Pleistocene glaciotectonised sediments from Eastern England. Quaternary Science Reviews, 27: 1350-1362.

geometry of these drag folds and the correlation of relatively distinct marker laminae across the faults indicate a normal/extensional sense of displacement. The faults are composed of several discrete planes with the individual fault planes being lined by either clay grade material or clean, matrix-poor sand. The latter appears to have been derived by the dragging of sand laminae in the adjacent walls into the fault during extensional movement. Such movement would have created 'space' along the fault plane enabling the accommodation of this material. The structurally lower of the two faults is more diffuse in nature and marked by a 5 to $8 \mathrm{~mm}$ wide zone of deformation.

The diamicton layers (BG4/E; BG4/F (see Fig. 2) within the BGTM are composed of a massive to weakly-laminated to massive, poorly-sorted, fine- to medium-grained silty sand (Fig. 5) which possess an open to very open packed, matrix-supported texture. Many of the larger sand grains are clustered and form crude circular grain alignments or 'galaxy structures' characteristic of rotational ductile deformation (van der Meer, 1997) or turbulent flow (Phillips, 2006). Despite the common presence of clay-grade material throughout the diamicton layers, skelsepic and lattisepic plasmic fabrics are either very poorly developed or absent. This matrix is rich in very fine-grained, highly birefringent, carbonate which tends to obscure plasmic fabrics, if present.

The weakly developed or preserved lamination or fine-scale stratification (e.g. in samples BG4/E, BG4/F) is defined by both a variation in grain size and modal proportion of matrix. The matrix-rich laminae possess an open packed matrixsupported texture resulting in a highly 'dilated' appearance. The sand-rich laminae are clast-supported with a variably preserved intergranular porosity. In samples BG4/E and BG4/F, which were taken from an elongate lens or augen of diamicton, the lamination is highly folded and off-set by a number of sub-horizontal to moderately dipping faults (Fig. 5). The folds are recumbent to moderately inclined, asymmetrical structures which locally possess highly attenuated or boudinaged limbs (Fig. 5). These microscale folds are similar in style to the macroscopic structures seen in outcrop. Disharmonic parasitic folds associated with these microscopic structures are consistent with the sediments having possessed a high pore water content and/or pressure during folding. The folds are dissected by several sets of faults indicating that ductile folding was followed by at least one phase of brittle faulting. Three sets of faults have been recognised: (i) normal (extensional) faults dipping at approximately $30^{\circ}$ to $40^{\circ}$; (ii) moderate to gently inclined reverse faults dipping at approximately $25^{\circ}$ to $35^{\circ}$; and (iii) a set of low-angle to subhorizontal thrusts (Fig.5). Individual fault planes are defined by a narrow zone of shear in which the individual sand and diamicton laminae are highly attenuated. The relative age relationships between these faults is uncertain. However, the sinistral sense of displacement recorded by these structures is consistent with them having formed during the same deformation event, with the normal and reverse faults possibly forming as Reidel shears during thrusting. The direction of movement (northerly directed) recorded by 
Lee JR, Phillips E. 2008. Progressive soft sediment deformatio within a subglacial shear zone - a hybrid mosaic-pervasive deformation model for Middle Pleistocene glaciotectonised sediments from Eastern England. Quaternary Science Reviews, 27: 1350-1362.

these brittle structures is comparable to the sense of asymmetry of the earlier formed fold structures. This suggests that both the folding and faulting probably occurred during the same northerly directed progressive deformation event, with thrusting occurring in response to continued shortening of the sedimentary pile.

The disharmonic nature of the folds suggests that the BGTM possessed a relatively high pore water content and/or pressure during folding. Consequently, pore water content must have fallen after folding had ceased, enabling brittle faulting to occur. Elsewhere in thin section, the fine-scale stratification within the till is variably overprinted due to the liquefaction and remobilisation of the sand laminae (Fig. 6). It is probable that the sand underwent localised liquefaction during folding, resulting the homogenisation and patchy overprinting of the lamination, leading to the 'mottled' appearance of the till in thin section. The remobilised fine- to coarsegrained, clean sand also fills a number of irregular veins (hydrofractures) which cross-cut the folds and faults (Fig. 6). These microstructural relationships clearly indicate that pore water pressure increased again during a later stage of the deformation of the BGTM. Furthermore, this pressure increase locally exceeded the cohesive strength of the sediments leading to localised hydrofracturing of the till.

\section{Evolution of the Stratified Diamicton Complex}

\subsection{Primary mode of sedimentation}

The primary sedimentary features, where preserved within the 'lower facies', demonstrate that the BGTM forms part of a gradational continuum with the underlying glaciodeltaic sands of the MSM. This upwards transition from the MSM to the BGTM is thought to record a gradual change in depositional environments from a fine-grained outwash delta to a subaqueous debris fan associated with an ice advance into the glaciolacustrine basin. Sedimentary evidence indicates that the BGTM was deposited as a series of underflows introducing masses of poorly-sorted cohesive sediment (diamicton beds) and sediment plumes (sandy silt and sandy clay laminae) into the standing body of water, plus pulses of sorted outwash sand as turbidity currents. The upwards transition within the till to a more pebbly facies probably represents the localised input of coarse glacial outwash into the lacustrine basin. This coarsening upwards sequence and introduction of more proximal detritus into the lake is thought to record the progradation of the debris fan into the lake, possibly accompanying a change in the position of the glacier margin.

Detailed analysis of the erratic content within the BGTM reveals that it contains significant proportions of soft low-durability lithologies including Magnesian Limestone, Carboniferous coal and limestone from northern England and Central Scotland. (Lee et al., 2004a). This suggests that the till was deposited by British ice that flowed down east coast of England and across the study site from the north (Lee et al., 2002). 
Lee JR, Phillips E. 2008. Progressive soft sediment deformatio within a subglacial shear zone - a hybrid mosaic-pervasive deformation model for Middle Pleistocene glaciotectonised sediments from Eastern England. Quaternary Science Reviews, 27: 1350-1362.

\subsection{Sand lenses: sedimentary or tectonic?}

The lenticular lenses of sand observed with the diamicton complex are interesting features and similar structures have been reported widely within the literature. Their augen-like appearance has been often explained by the shearing of incorporated masses of sand by either gravitational flow (Eyles et al., 1985; McCarroll and Harris, 1992; Lunkka, 1994) or subglacial deformation (Hart and Boulton, 1991; McCarroll and Harris, 1992; Hart and Roberts, 1994).

The sand lenses or augen within the BGTM represent the detached hinges of tight to very tight asymmetrical folds that formed in response to northerly-directed shear during subglacial deformation. The heavy mineral composition of the sand indicates that the lenses are derived from the underlying MSM (Lee, 2003). This suggests that part of this laterally extensive sand body was being fragmented during the progressive shearing of the structurally overlying BGTM. During the initial stages of this shearing event, bedding within the MSM would have been deformed into a series of 'linked' antiforms and synforms (Fig. 7). As deformation continued the folds would have been progressively dismembered in response to either ductile shearing of the limbs (Model I, Fig. 7), or the formation of low-angle thrusts which detached the fold from the underlying sands as a result of continued shortening of the sedimentary pile (Model II, Fig. 7). The geometry of the folds preserved within the sand lenses/augen, their derivation from the stratigraphically lower parts of the succession (the MSM), and subsequent emplacement into a structurally higher position within the BGTM suggests that they were formed as a result of initial ductile folding followed by apparently more brittle thrusting, i.e. Model II (Fig. 7). This model provides a mechanism for vertically redistributing sediment within the actively deforming pile.

\subsection{Mechanisms of glaciotectonic deformation}

The geometry of the glaciotectonic structures (folds, thrusts, faults and hydrofractures) developed in the BGTM, coupled with their tectonostratigraphic relationships to one another, can be used to unravel the characteristics and mechanisms involved during the deformation of this complex stratified till sequence. Macroscopic (field) and microstructural evidence is consistent with these deformation structures having formed during a single northeast-directed shearing event, associated with glacier ice overriding from the southwest. Although a detailed regional reconstruction of the glacial history of the region is beyond the scope of this paper, this study does have significant implications regarding the chronology and pattern of lowland glaciation within eastern England. Firstly, it is worthwhile noting that two opposite directional modes of ice advance are evident associated with the initial deposition ('northern' ice advance) of the BGTM and its subsequent deformation ('southwest ice advance'). Furthermore, the kinematics of deformation indicate that the BGTM had not dewatered prior to glaciotectonic deformation suggesting that only a short period of time had lapsed between the two ice advances. 
Lee JR, Phillips E. 2008. Progressive soft sediment deformatio within a subglacial shear zone - a hybrid mosaic-pervasive deformation model for Middle Pleistocene glaciotectonised sediments from Eastern England. Quaternary Science Reviews, 27: 1350-1362.

The deposition and deformation of the BGTM, therefore, records the complex interaction of two ice margins associated with two different bodies of ice. The northwards retreat of ice that deposited the BGTM apparently allowed the ice advance from the southwest to advance into a temporary basin that existed between these two ice sheets, deforming the pre-existing BGTM sediment pile. This ice advance is probably associated with the deposition of the Weybourne Town Till Member (formerly known as the 'Marly Drift') across much of northern East Anglia (West and Donner, 1956; Perrin et al., 1979; Ehlers et al., 1991; Fish and Whiteman, 2001).

The variation in style and intensity of subglacial deformation of the BGTM beneath the ice advance from the southwest was controlled, at least in-part, by temporal and spatial changes in intergranular pore water content and/or pressure during subglacial accretion and thickening of the sediment pile. Macroscopic and micromorphological evidence has allowed this single progressive shearing event to divided into three phases or stages (D1 to D3).

The early stages of deformation (D1) were characterised by locally intense ductile folding. The disharmonic nature of the folds deforming the BGTM (at both a macro- and microscopic scale) indicates that elevated pore water conditions (contents and/or pressures) existed during D1. The effect of this was to reduce the effective shear strength of the sediment pile, enabling the formation of highly attenuated, recumbent to locally rootless folds. In metamorphic terrains, such features are typical of high shear strains. In glacial sediments, the existence of high pore water content and/or pressure during deformation can aid the formation of these detached/rootless structures even under comparatively low levels of strain. The liquefaction and remobilisation of the sand beds or laminae during the progressive shearing of the fold would have aided in the attenuation and boudinage of the limbs, leading to the eventual detachment of the fold hinges. This 'fluid enhanced' shearing was accompanied by localised liquefaction of the sediment pile and remobilisation of the intercalated fine- and coarse sand. The proposed subaqueous depositional setting of the BGTM means that this complex stratified till sequence would have already been water saturated, even as it was initially being overridden by the glacier. The confining pressure exerted by the overlying glacier, coupled with the sequence of impermeable layers (diamicton) and permeable (sand) within the BGTM would have impeded subglacial drainage and led to a progressive increase in pore water pressure.

The D1 event was followed by a phase of thrusting and apparently associated normal and reverse faulting (D2). The onset of this more brittle phase of deformation indicates there was a marked change in the hydrodynamic system beneath the overriding glacier ice that allowed pore water to escape, leading to the 'locking' of the subglacial shear zone. The fall in pore water content led to an increase in the cohesive strength of the sediment pile enabling the propagation of the low-angle to sub-horizontal thrusts through the diamicton layers. Thrusting would have resulted 
Lee JR, Phillips E. 2008. Progressive soft sediment deformatio within a subglacial shear zone - a hybrid mosaic-pervasive deformation model for Middle Pleistocene glaciotectonised sediments from Eastern England. Quaternary Science Reviews, 27: 1350-1362.

in the tectonic thickening of the sediment pile and stacking of thrust-repeated slices of interlayered sand and diamicton. One of the most obvious effects of this was the detachment and transportation of folded masses (lenses/augen) of sand from the underlying MSM along low-angle thrusts through the deforming layer. The overall affect of thrusting on till thickness is difficult to establish due the absence of any distinct marker horizons within the BGTM. The sense of displacement on the normal and reverse faults, and spatially related extensional shears, is consistent with their development as sets of Reidel shears (see inset Fig. 6) within the subglacial shear zone during D2.

Continued deformation resulted in the progressive loading of the BGTM leading an increase in pore water pressures and the formation of hydrofractures, as well as localised liquefaction and injection of fluidised sand into a network of crosscutting veins (D3). Sand-filled hydrofractures are present within the 'upper mélange facies' at Bacton Green, however, such features are not widely developed suggesting that hydrofracturing was not exclusively responsible for the dewatering of the subglacial shear zone. An additional dewatering mechanism could relate to the intergranular flow of pore water caused by loading during subglacial sediment thickening. Final dewatering of the sediment pile may have only begun to occur during the retreat phase of the glacier, accompanied by the unloading of the Bacton Green sedimentary sequence.

\subsection{Temporal and spatial evolution of the subglacial shear zone}

The relationships between the different deformation events recognised at Bacton Green clearly demonstrates that the evolution of the subglacial shear zone beneath the advancing 'North Sea ice' was complex both spatially and temporally (Fig. 8). Two contrasting models have recently been presented to explain the evolution and deformation style of subglacial tills within the geological record. The first argues that subglacial deformation is pervasive, and that all subglacial till facies produced by different processes such as melt-out and lodgement ultimately undergo shearing and should thus be classified as deforming bed tills (van der Meer et al., 2003; Menzies et al., 2006). The second model argues that a spatial and temporal 'mosaic' comprising actively deforming and stable (non-deforming) zones develop within the subglacial deforming bed (Piotrowski and Kraus, 1997) in response to either the degree of water-induced decoupling at the IBI (Hoffman and Piotrowski, 2001), or the ability of the subglacial bed to drain inter-granular pore-water (Piotrowski et al., 2004).

The macroscopic and micro-scale evidence from the stratified diamicton complex at Bacton Green suggests that elements of both the 'pervasive' and 'mosaic' deforming bed models can be invoked to explain the deformation of the BGTM. Deformation is 'pervasive' in respect that shear stress was being transmitted throughout the entire subglacial bed. Indeed the presence of highly attenuated to rootless recumbent folds throughout both the 'upper mélange facies' and the 'lower facies' could be used to suggests that relatively high strains were superimposed upon 
Lee JR, Phillips E. 2008. Progressive soft sediment deformatio within a subglacial shear zone - a hybrid mosaic-pervasive deformation model for Middle Pleistocene glaciotectonised sediments from Eastern England. Quaternary Science Reviews, 27: 1350-1362.

the entire thickness of the BGTM (c. $14 \mathrm{~m}$ thick) with ductile folding also effecting the underlying MSM (see Fig. 8); as predicted by Hart and Boulton (1991) and van der Wateren et al. (2000). However, the style and intensity of deformation recorded by the BGTM is spatially variable and was apparently controlled by the variation in inter-granular pore water content and the rate of till thickening. Ductile shear imposed by the overriding glacier ice would have been preferentially focused, or partitioned, into the relatively weaker, 'water-rich' (dilated) parts of the sequence. At Bacton Green, these 'weaker' zones were apparently located at structurally/stratigraphically higher levels with the deforming bed. The result is the observed increase in the intensity of deformation upward through the BGTM and the generation of the structurally complex 'mélange facies' in the upper part of this till complex beneath the overriding ice (Fig. 8). This highly disrupted facies is thought to have accommodated the majority of the shear transmitted into the deforming bed and, therefore, the bulk of the displacement achieved by the overriding glacier ice (see Fig. 8). Initial development of the subglacial shear zone during D1, eventually led to disruption of the upper part of the BGTM, may have been aided by the migration of pore water through the sediment pile. Dewatering was probably instigated by the overburden pressure exerted by the overriding ice and assisted by the tectonic thickening of the deforming bed as deformation progressed. The zone of fluid enhanced shear developed beneath the glacier would have provided an ideal pathway for fluid migration and water escape, with the overlying ice representing an impermeable 'cap' forcing water to travel laterally. The continued dewatering of the sedimentary sequence and possible introduction of additional subglacial meltwater from up-ice, as deformation progressed, would have led to the increasing dilation and weakening of the BGTM. This weakening of the sediment pile would have resulted in the continued development (growth) of the subglacial shear zone which expanded both vertically (downwards - lowering the base of the deforming bed) and laterally (sideways), to effect more of the glacier bed. In theory this process of subglacial shear zone expansion would lead to a continuum from heterogeneous (c.f. Piotrowski and Kraus, 1997; Hoffman and Piotrowski, 2001) to more pervasive (c.f. van der Meer et al., 2003; Menzies et al., 2006) deformation occurring beneath the glacier. If the water content of the sediment increased above a critical point the glacier may be decoupled from its bed. However, if the increase in pore water pressure and/or content is terminated or fluid content of the sediment decreases, for example in response to large-scale hydrofracturing and water-escape, fluid enhanced shearing would be arrested, possibly leading to the 'locking up' and 'collapse' of the subglacial shear zone.

Seasonal or longer term fluctuations in pore water pressure and/or content in the subglacial environment may lead to several periods of 'expansion' and 'contraction' of the subglacial shear zone. The result would be that the sediments within the deforming bed would be imprinted with a complex sequence of cross-cutting, polyphase deformation structures (e.g. D1 to D3 at Bacton Green). At Bacton Green, 
Lee JR, Phillips E. 2008. Progressive soft sediment deformatio within a subglacial shear zone - a hybrid mosaic-pervasive deformation model for Middle Pleistocene glaciotectonised sediments from Eastern England. Quaternary Science Reviews, 27: 1350-1362.

D2 deformation was more brittle in character, leading to thrusting and tectonic thickening of the sediment pile. This change from ductile folding during D1 to a predominantly brittle deformation mechanism during D2 is thought to record the locking up and dewatering of the subglacial shear zone. Thrusting and the stacking of tectonic slices of BGTM would have accommodated continued/further shear imposed by the overriding ice. However, the amount of shear transmitted through the deforming bed profile would have become progressively lower, leading to a relative rise in the elevation base of the deforming bed (Boulton, 1987; Hart et al., 1990). The migration of the expelled pore water, and its concentration elsewhere within the BGTM, would lead to ductile shearing being switched (partitioned) into a weaker part of the sediment pile. The result would be a shifting, anastomosing pattern of deformation within the deforming bed. This process of 'switching' between actively deforming zones, means that the D1 to D3 sequence of deformation would migrate through the sediment pile with time.

\section{Conclusions}

The study of the stratified diamicton complex at Bacton Green contributes to an understanding of the mechanisms of subglacial deformation and its evolution in time and space.

- Sedimentary features, where preserved, indicate that the stratified diamicton complex (BGTM) was deposited by processes of mass flow, rapid rain-out, and turbidity current activity within a standing body of water. The relationship of the 'till' to underlying sands, records the switch from deposition on a glaciolacustrine delta to that of an ice-proximal subaqueous debris fan.

- This stratified sedimentary sequence locally shows evidence of intense deformation including recumbent to asymmetrical folds, thrusts, normal and reverse faults, as well as sand-filled hydrofractures. The geometry and relationship of these structures to one-another records three phases of deformation: ductile deformation associated with elevated pore water content / pressure (D1); brittle deformation following dewatering (D2); and hydrofracturing associated with a second dewatering event either as a consequence of deformation-induced loading or glacier unloading on ice retreat (D3).

- The range and type of tectonic structures reveal that the deformation was caused within a subglacial shear zone caused by the pre-existing sediment pile being overridden by an ice advance from the southwest.

- The primary control on this deformation appears to be the spatial and temporal distribution of pore water and the rate of till thickening caused by subglacial thrusting and shortening. The movement of sediments downwards through the subglacial deforming bed causes dewatering enabling the cohesive shear strength of the material to increase and deformation to switch from ductile to brittle. 
Lee JR, Phillips E. 2008. Progressive soft sediment deformatio within a subglacial shear zone - a hybrid mosaic-pervasive deformation model for Middle Pleistocene glaciotectonised sediments from Eastern England. Quaternary Science Reviews, 27: 1350-1362.

- The spatial arrangement and style of deformation reveals a degree of deformation partitioning with distinctive 'stable' and 'deforming' zones evident forming an apparent 'mosaic' within the deforming bed. Lower strain areas at the base of the deforming layer on the basis of the model presented here, appear to be particularly susceptible to this deformation partitioning.

- The study reveals a complex ice marginal pattern in northern East Anglia during the Middle Pleistocene. The BGTM was deposited during an ice advance from the north, upon retreat of this ice margin, ice flowing from the southwest overrode the site deforming the BGTM. This second ice advance is considered to be associated with the deposition of the chalky Weybourne Town Till of north Norfolk.

\section{Acknowledgements}

The authors wish to thank Brian Moorlock, Steven Pawley and Helen Burke for their comments on an earlier version of the manuscript. Adrian Palmer is thanked for his assistance with the manufacturing of the thin sections. Jim Rose and anonymous referee are thanked for their constructive comments on the manuscript. Funding for this research was provided in two phases: (1) RHUL/BGS (NERC) studentship received by JRL between 2000-2003; (2) BGS (NERC) funding via the Quaternary Palaeoenvironments and Landsystems project between 2005-2007. Both authors publish with the permission of the Executive Director of the British Geological Survey (NERC).

\section{References}

Alley, R.B. 1989. Water-pressure coupling of sliding and bed deformation: I. Water systems. Journal of Glaciology, 35, 108-118.

Alley, R.B., Blankenship, D.D., Bentley, C.R., Rooney, S.T. 1987. Till beneath Ice Stream B, 4. A coupled ice-till flow model. Journal of Geophysical Research, 92, 89218929.

Banham, P.H. 1975. Glaciotectonic structures: a general discussion with particular reference to the contorted drift of Norfolk. In: Wright, A.E., Moseley, F. (eds). Ice Ages: Ancient and Modern, Seel House Press, Liverpool, 69-94.

Banham, P.H. Gibbard, P.L., Lunkka, J.P., Parfitt, S.A., Preece, R.C., Turner, C. 2001. A critical assessment of 'A new glacial stratigraphy for Eastern England'. Quaternary Newsletter, 93, 5-14.

Bentley, C.R. 1997. Rapid sea-level rise soon from West Antarctic ice sheet collapse? Science, 275, 1077-1078. 
Lee JR, Phillips E. 2008. Progressive soft sediment deformatio within a subglacial shear zone - a hybrid mosaic-pervasive deformation model for Middle Pleistocene glaciotectonised sediments from Eastern England. Quaternary Science Reviews, 27: 1350-1362.

Boulton, G.S. 1986. A paradigm shift in glaciology. Nature, 322, 18.

Boulton, G.S. 1987. A theory of drumlin formation by subglacial sediment deformation. In: Menzies, J., Rose, J. (eds). Drumlin Symposium, Balkema, Rotterdam, pp.25-80.

Boulton, G.S., Jones, A.S. 1979. Stability of temperate ice caps and ice sheets resting on deformable sediment. Journal of Glaciology, 24, 29-43.

Boulton, G.S., Hindmarsh, R.C.A. 1987. Sediment deformation beneath glaciers: rheology and geological consequences. Journal of Geophysical Research, 92, 9059-9082.

Bowen, D.Q., Rose, J., McCabe, A.M., Sutherland, D.G. 1986. Quaternary Glaciations in England, Ireland, Scotland, and Wales. Quaternary Science Reviews, 5, 299-340.

Bowen, D.Q (ed.) 1999. A revised correlation of Quaternary deposits in the British Isles. Geological Society of London Special Report No. 23.

Broecker, W., Bond, G., Klas, M., Clark, E., McManus, J. 1992. Origin of the north Atlantic's Heinrich events. Climate Dynamics, 6, 265-273.

Carr, S.J. 1988. The last glaciation of the North Sea Basin. Unpublished PhD Thesis, Royal Holloway University of London.

Carr, S.J., Lee, J.A. 1998. Thin section production of diamicts: problems and solutions. Journal of Sedimentary Research, 68, 217-221.

Clark, P.U. 1994. Unstable behavior of the Laurentide Ice Sheet over deforming sediment and its implications for the climate change. Quaternary Research, 41, 19-25.

Clark, P.U., Alley, R.B., Pollard, D. 1999. Northern Hemisphere ice-sheet influences on global climate change. Science, 286, 1104-1111.

Ehlers, J., Gibbard, P.L. 1991. Anglian glacial deposits in Britain and the adjoining offshore regions. In: Ehlers, J., Gibbard, P. L., Rose, J. (eds). Glacial Deposits of Great Britain and Ireland, Balkema, Rotterdam, 17-24.

Ehlers, J., Gibbard, P.L., Whiteman, C.A. 1991. The glacial deposits of northwest Norfolk. In: Ehlers, J., Gibbard, P. L., Rose, J. (eds). Glacial Deposits of Great Britain and Ireland, Balkema, Rotterdam, 223-232. 
Lee JR, Phillips E. 2008. Progressive soft sediment deformatio within a subglacial shear zone - a hybrid mosaic-pervasive deformation model for Middle Pleistocene glaciotectonised sediments from Eastern England. Quaternary Science Reviews, 27: 1350-1362.

Evans, J., Dowdeswell, J.A., Ó Cofaigh, C., Benham, T.J., Anderson, J.B. 2006. Extent and dynamics of the West Antarctic Ice Sheet on the outer shelf of the Pine Island Bay during the last glaciation. Marine Geology, 230, 53-72.

Evans, D.J.A., Phillips, E.R., Hiemstra, J.F., Auton, C.A. 2006. Subglacial till: formation, sedimentary characteristics and classification. Earth Science Reviews, 78, 115-176.

Eyles, C.H., Eyles, N. 1983. Sedimentation in a large lake: a reinterpretation of the late Pleistocene stratigraphy at Scarborough Bluffs, Ontario, Canada. Geology, 11, 146-152.

Eyles, C.H., Eyles, N., Miall, A.D. 1985. Models of glaciomarine sedimentation and their application to the interpretation of ancient glacial sequences. Palaeogeography, Palaeoclimatology, Palaeoecology, 51, 15-84.

Eyles, N., McCabe, A.M. 1989. The Late Devensian (<22,000 YBP) Irish Sea Basin: the sedimentary record of a collapsed ice margin. Quaternary Science Reviews, 10, 307-351.

Fish, P.R., Whiteman, C.A. 2001. Chalk micropalaeontology and the provenancing of Middle Pleistocene Lowestoft Formation till in eastern England. Earth Surface Processes and Landforms, 26, 953-970.

Fischer, U.H., Clarke, G.K.C. 1997. Stick-slip sliding behaviour at the base of a glacier. Annals of Glaciology, 24, 390-396.

Fischer, U.H., Clarke, G.K.C., Blatter, H. 1999. Evidence for temporally varying sticky spots at the base of Trapridge Glacier, Yukon Territory, Cananda. Journal of Glaciology, 45, 352-360.

Gibbard, P.L., Moscariello, A., Bailey, H.W., Boreham, S., Koch, C., Lord, A.R., Whiteman, C.A. 2008. Comment: Middle Pleistocene sedimentation at Pakefield, Suffolk, England. Journal of Quaternary Science, 23, 85-92.

Hamblin, R.J.O, Moorlock, B.S.P., Rose, J. 2000. A New Glacial Stratigraphy for Eastern England. Quaternary Newsletter, 92, 35-43.

Hart, J.K. 1990. Proglacial glaciotectonic deformation and the origin of the Cromer Ridge push moraine complex, North Norfolk, England. Boreas, 19, 165-180.

Hart, J.K., Hindmarsh, R.C.A., Boulton, G.S. 1990. Styles of subglacial glaciotectonic deformation within the context of the Anglian ice-sheet. Earth Surface Processes and Landforms, 15, 227-241. 
Lee JR, Phillips E. 2008. Progressive soft sediment deformatio within a subglacial shear zone - a hybrid mosaic-pervasive deformation model for Middle Pleistocene glaciotectonised sediments from Eastern England. Quaternary Science Reviews, 27: 1350-1362.

Hart, J.K., Boulton, G.S. 1991. The interrelation of glaciotectonic and glaciodepositional processes within the glacial environment. Quaternary Science Reviews, 10, 335-350.

Hart, J.K., Roberts, D.H. 1994. Criteria to distinguish between subglacial glaciotectonic and glacimarine sedimentation: I. Deformation styles and sedimentology. Sedimentary Geology, 91, 191-213.

Hoeoke, R. LeB., Hanson, B., Iverson, N.R., Jansson, P., Fischer, U.H. 1997. Rheology of till beneath Storglaciären, Sweden. Journal of Glaciology, 43, 172-179.

Hoffmann, K., Piotrowski, J.A. 2001. Till m!elange at Amsdorf, central Germany: sediment erosion, transport and deposition in a complex, soft-bedded glacial system. Sedimentary Geology, 140, 215-234.

Hughes, T. 1996. Can ice sheets trigger abrupt climate change? Arctic and Alpine Research, 28, 448-465.

Knight, J. 2002. Glacial sedimentary evidence supporting stick-slip basal ice flow. Quaternary Science Reviews, 21, 975-983.

Lee, J.R. 2001. Genesis and palaeogeographic significance of the Corton Diamicton (basal member of the North Sea Drift Formation), East Anglia, UK. Proceedings of the Geologist's Association, 112, 43-67.

Lee, J.R. 2003. Early and Middle Pleistocene lithostratigraphy and palaeoenvironments in northern East Anglia, UK. Unpublished PhD Thesis, Royal Holloway University of London.

Lee, J.R., Rose, J., Riding, J.B., Hamblin, R.J.O., Moorlock, B.S.P. 2002. Testing the case for a Middle Pleistocene Scandinavian glaciation in Eastern England: evidence for a Scottish ice source for tills within the Corton Formation of East Anglia, UK. Boreas, 31, 345-355.

Lee, J.R., Booth, S.J., Hamblin, R.J.O., Jarrow, A.M., Kessler, H., Moorlock, B.S.P., Morigi, A.N., Palmer, A., Pawley, S.J., Riding, J.B., Rose, J. 2004a. A new stratigraphy for the glacial deposits around Lowestoft, Great Yarmouth, North Walsham and Cromer, East Anglia, UK. Bulletin of the Geological Society of Norfolk, 53, 3-60 . 
Lee JR, Phillips E. 2008. Progressive soft sediment deformatio within a subglacial shear zone - a hybrid mosaic-pervasive deformation model for Middle Pleistocene glaciotectonised sediments from Eastern England. Quaternary Science Reviews, 27: 1350-1362.

Lee, J.R., Rose, J., Hamblin, R.J.O., Moorlock, B.S.P. 2004b. Dating the earliest lowland glaciation of eastern England: the pre-Anglian early Middle Pleistocene Happisburgh Glaciation. Quaternary Science Reviews, 23, 1551-1566.

Lee, J.R., Rose, J., Candy, I., Barendregt, R.W., Moorlock, B.S.P., Riding, J.B., Hamblin, R.J.O. 2008. Reply: Middle Pleistocene sedimentation at Pakefield, Suffolk, England. Journal of Quaternary Science, 23, 93-98.

Licciardi, J.M., Clark, P.U., Jenson, J.W., MacAyeal, D.R. 1998. Deglaciation of a softbedded Laurentide Ice Sheet. Quaternary Science Reviews, 17, 427-448.

Lunkka, J.P. 1994. Sedimentology and lithostratigraphy of the North Sea Drift and Lowestoft Till Formations in the coastal cliffs of NE Norfolk. Journal of Quaternary Science, 9, 209-233.

McCarroll, D., Harris, C. 1992. The glacigenic deposits of western Lleyn, North Wales: terrestrial or marine? Journal of Quaternary Science, 7, 19-29.

McCarroll, D., Rijsdijk, K.F. 2003. Deformation styles as a key for interpreting glacial depositional environments. Journal of Quaternary Science, 18, 473-489.

Menzies, J. 2000. Micromorphological analyses of microfabrics and microstructures, indicative of deformation processes, in glacial sediments. In: Maltman, A.J., Hubbard, B., Hambrey, M.J. (eds.). Deformation of Glacial Materials. Geological Society Special Publication No. 176., 245-258.

Menzies, J., van der Meer, J.J.M., Rose, J. 2006. Till - as a glacial "tectomict", its internal architecture, and the development of a "typing" method for till differentiation. Geomorphology, 75, 172-200.

Perrin, R.M.S., Rose, J., Davies, H. 1979. The distribution, variation and origins of pre-Devensian tills in eastern England. Philosophical Transactions of the Royal Society of London, B287, 535-570.

Phillips, E.R. 2006. Micromorphology of a debris flow deposit: evidence of basal shearing, hydrofracturing, liquefaction and rotational deformation during emplacement. Quaternary Science Reviews, 25, 720-738.

Piotrowski, J.A., Kraus, A. 1997. Response of sediment to ice sheet loading in northwestern Germany: effective stresses and glacier bed stability. Journal of Glaciology, 43, 495-502. 
Lee JR, Phillips E. 2008. Progressive soft sediment deformatio within a subglacial shear zone - a hybrid mosaic-pervasive deformation model for Middle Pleistocene glaciotectonised sediments from Eastern England. Quaternary Science Reviews, 27: 1350-1362.

Piotrowski, J.A., Mickelson, D.M., Tulaczyk, S., Krzyszkowski, D., Junge, F.W., 2001. Were deforming subglacial beds beneath past ice sheet really widespread? Quaternary Science Reviews, 86, 139-150.

Piotrowski, J.A., Larsen, N.K., Junge, F.W. 2004. Reflections on soft subglacial beds as a mosaic of deforming and stable spots. Quaternary Science Reviews, 23, 993-1000.

Roberts, D.H., Hart, J.K. 2005. The deforming bed characteristics of a stratified till assemblage in north East Anglia, UK: investigating controls on sediment rheology and strain signatures. Quaternary Science Reviews, 24, 123-140.

Slater, G. 1926. Glacial tectonics as reflected in disturbed glacial deposits. Proceedings of the Geologists' Association, 37, 392-400.

van der Meer, J.J.M. 1993. Microscopic evidence of subglacial deformation. Quaternary Science Reviews, 12, 553-587.

van der Meer, J.J.M. 1997. Particle and aggregate mobility in till: microscopic evidence of subglacial processes. Quaternary Science Reviews, 16, 827-831.

van der Meer, J.J.M., Menzies, J., Rose, J., 2003. Subglacial till: the deforming glacier bed. Quaternary Science Reviews, 22, 1659-1685.

van der Wateren, F.M., Kluiving, S.J., Bartek, L.R. 2000. Kinematic indicators of subglacial shearing. In: Maltman, A.J., Hubbard, B., Hambrey, J.M. (eds.). Deformation of Glacial Materials. Geological Society of London Special Publications No. 176., 259291.

West, R.G., Donner, J.J. 1956. The glaciations of East Anglia and the East Midlands: a differentiation based on stone orientation measurements of the tills. Quarterly Journal of the Geological Society of London, 112, 146-184.

\section{Figure Captions}

Figure 1. Map showing the study location of Bacton Green, northern East Anglia, UK.

Figure 2. Cross-section of the cliffs at Bacton Green, Norfolk, showing the stratigraphy and structure of the deposits investigated. Composite logs summarising the primary lithofacies and shown for three transects $(A, B, C)$ and $D$ shows the location of thin section samples.

Figure 3. Photographs showing deformation structures within the Bacton Green Till Member. (a) Isoclinal folding and thrust planes developed in sand layers; (b) Sand 
Lee JR, Phillips E. 2008. Progressive soft sediment deformatio within a subglacial shear zone - a hybrid mosaic-pervasive deformation model for Middle Pleistocene glaciotectonised sediments from Eastern England. Quaternary Science Reviews, 27: 1350-1362.

beds offset by northerly dipping normal fault and associated extensional shear band; (c) An augen or lens of laminated sand deformed internally by an asymmetrical fold. The lamination within the fold hinge is deformed by small-scale disharmonic, parasitic folds. The shape of the augen / lens and fold asymmetry record the application of shear from the southwest; (d) layered beds of sand and diamicton deformed by a long-angle thrust plane; (e) thinly-laminated sand and diamicton showing reverse faulting and north-verging kink-like folds; (f) en echelon kink folding developed within thin beds of diamicton.

Figure 4. Annotated scans of thin sections BG4/A and BG4/C.

Figure 5. Annotated scans of thin sections BG4/E and BG4/F.

Figure 6. Schematic diagram showing the range of deformation structures associated with the development of a subglacial shear zone within the Bacton Green Till Member. Note that there is an overall increase in the apparent intensity of deformation upwards through the sequence.

Figure 7. Mechanisms for the development of detached fold hinges within the Bacton Green Till Member. Model 1: Shearing and attenuation of fold limbs leading to boudinage and modification of fold hinges. Model 2: Progressive dismemberment and attenuation of folds during shearing along major thrust planes.

Figure 8. Progressive deformation model showing the development of various shear structures using a hybrid 'mosaic' and 'pervasive' deforming bed model. 


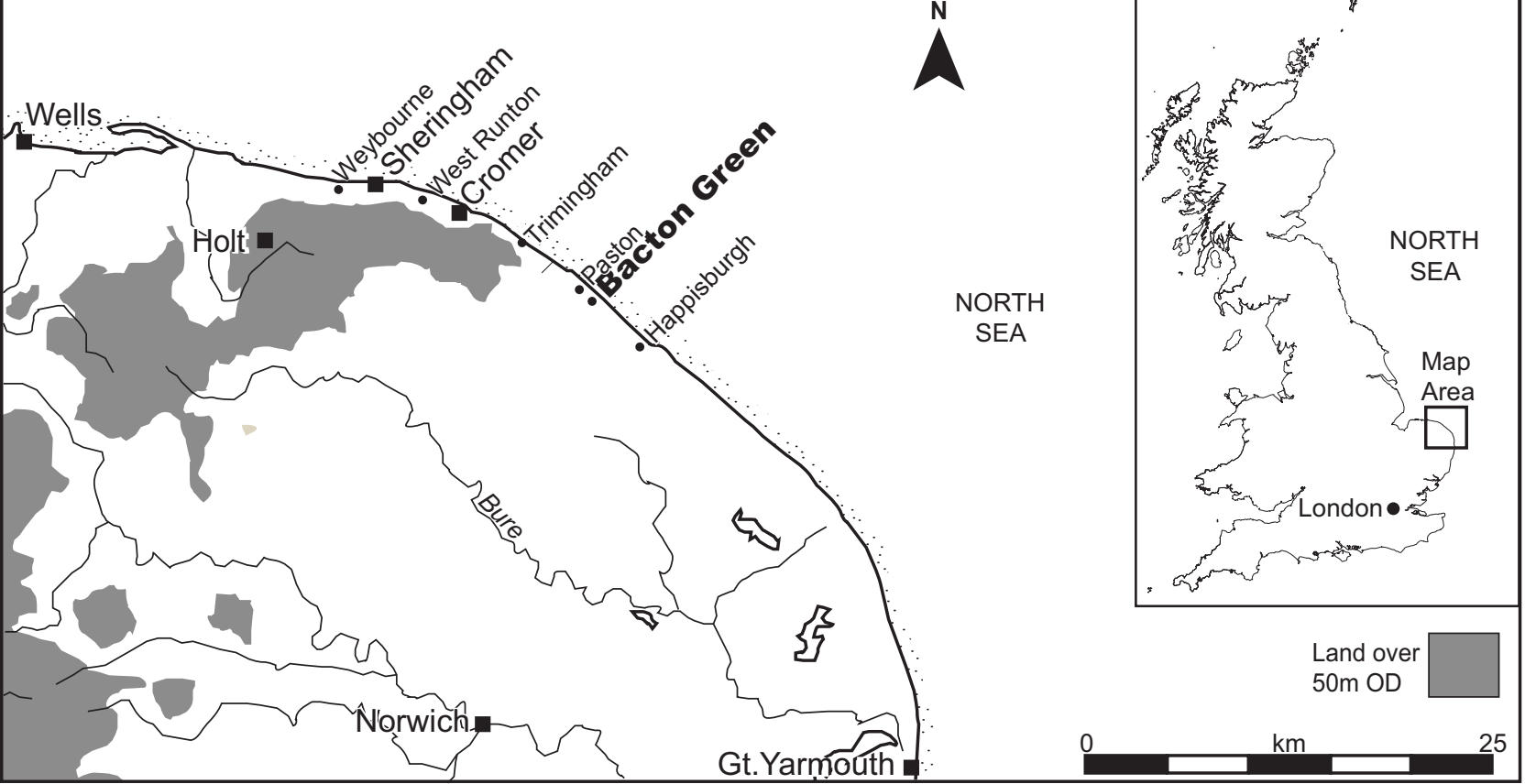

FIGURE 1 


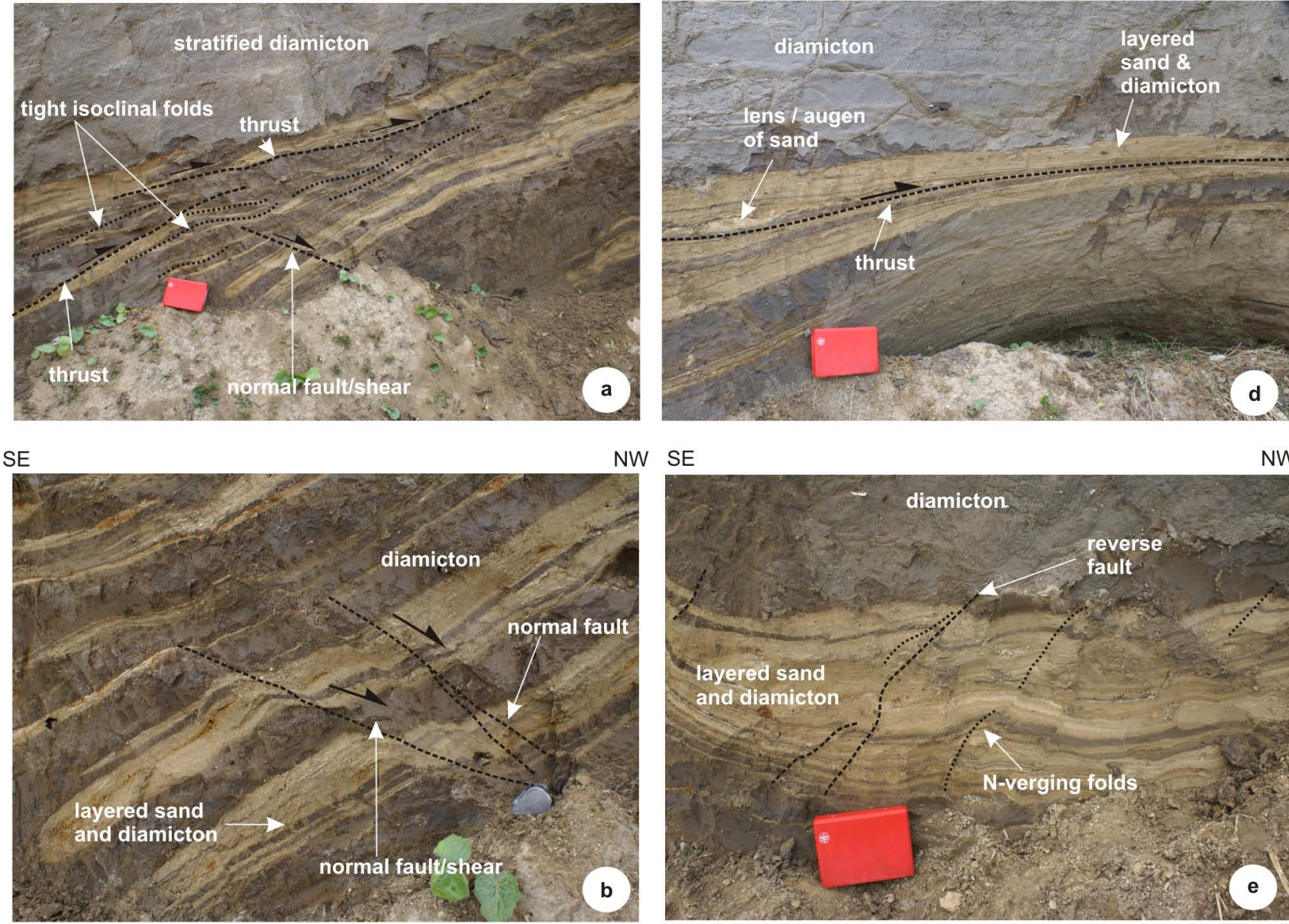

S de

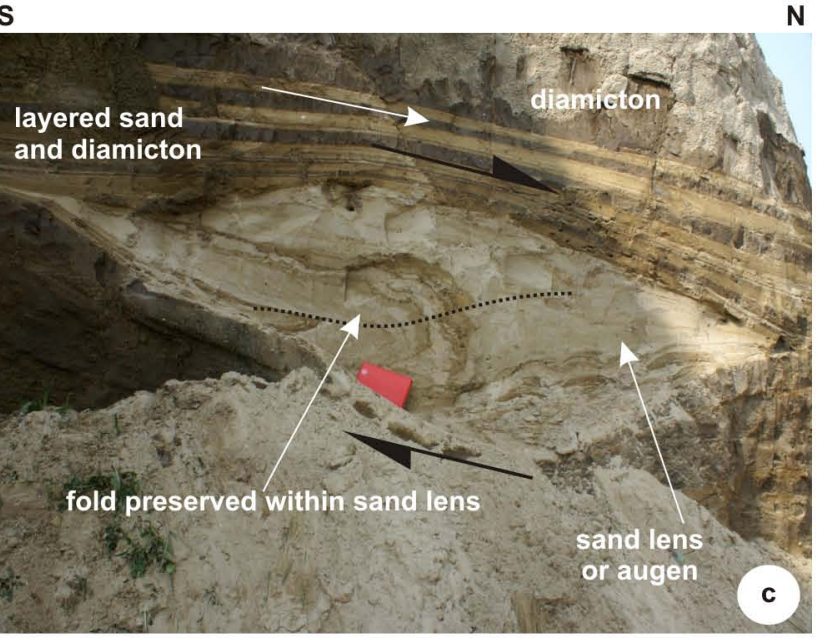

N S

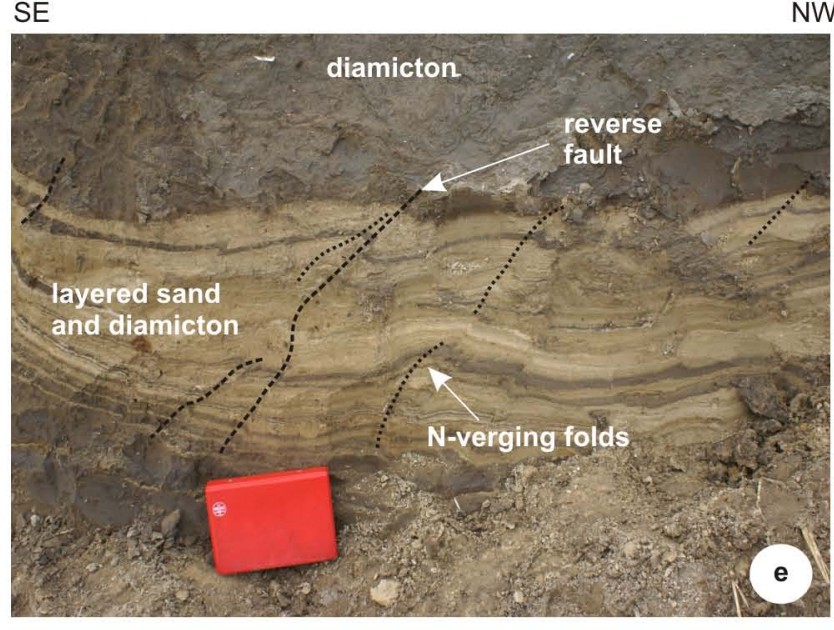

diamicton

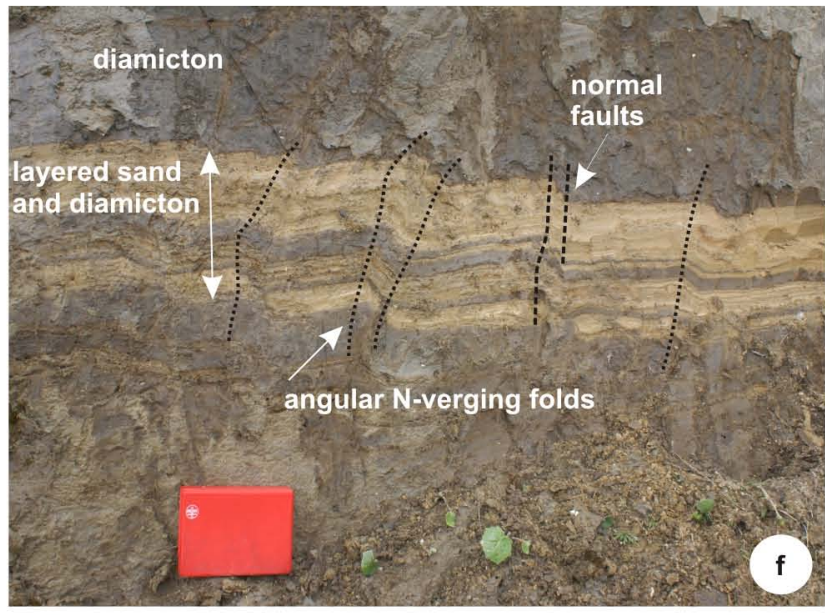

\section{Fig. 3}



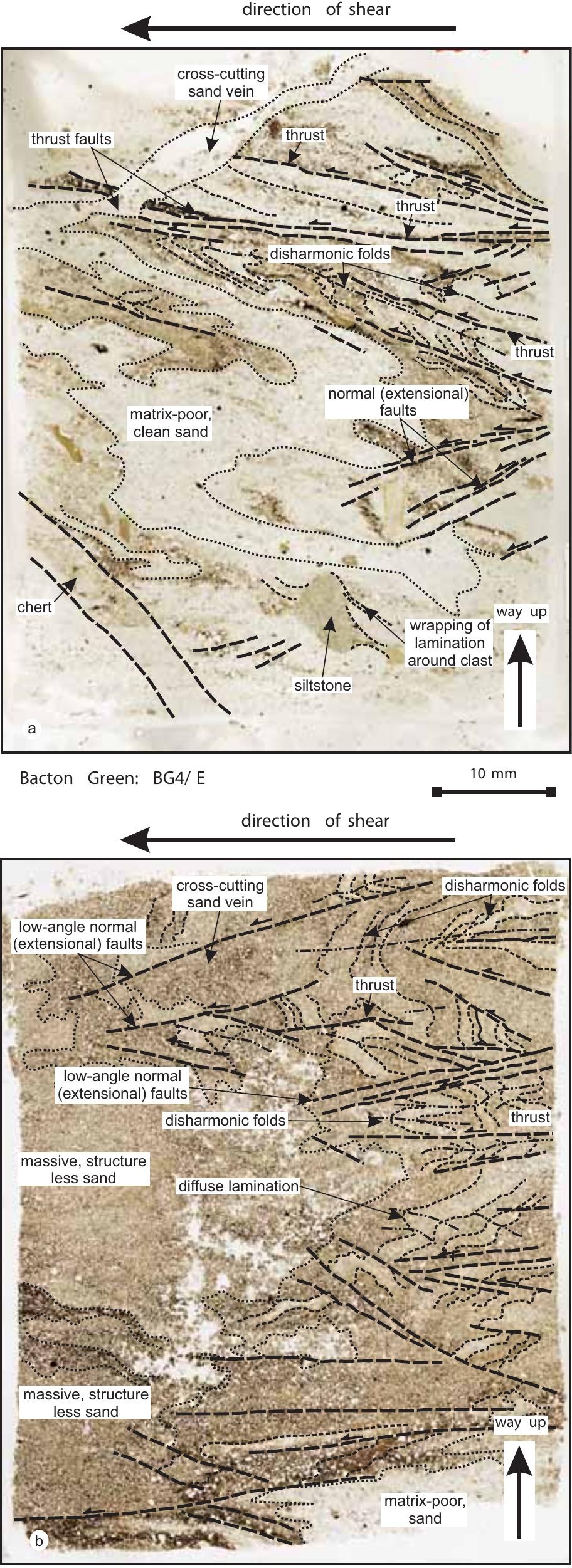

Bacton Green: BG4/ F

$\ldots$ sense of displacement on faults

- - fault

-..-.-. lamination

$-\cdot-\cdot-$ folds 


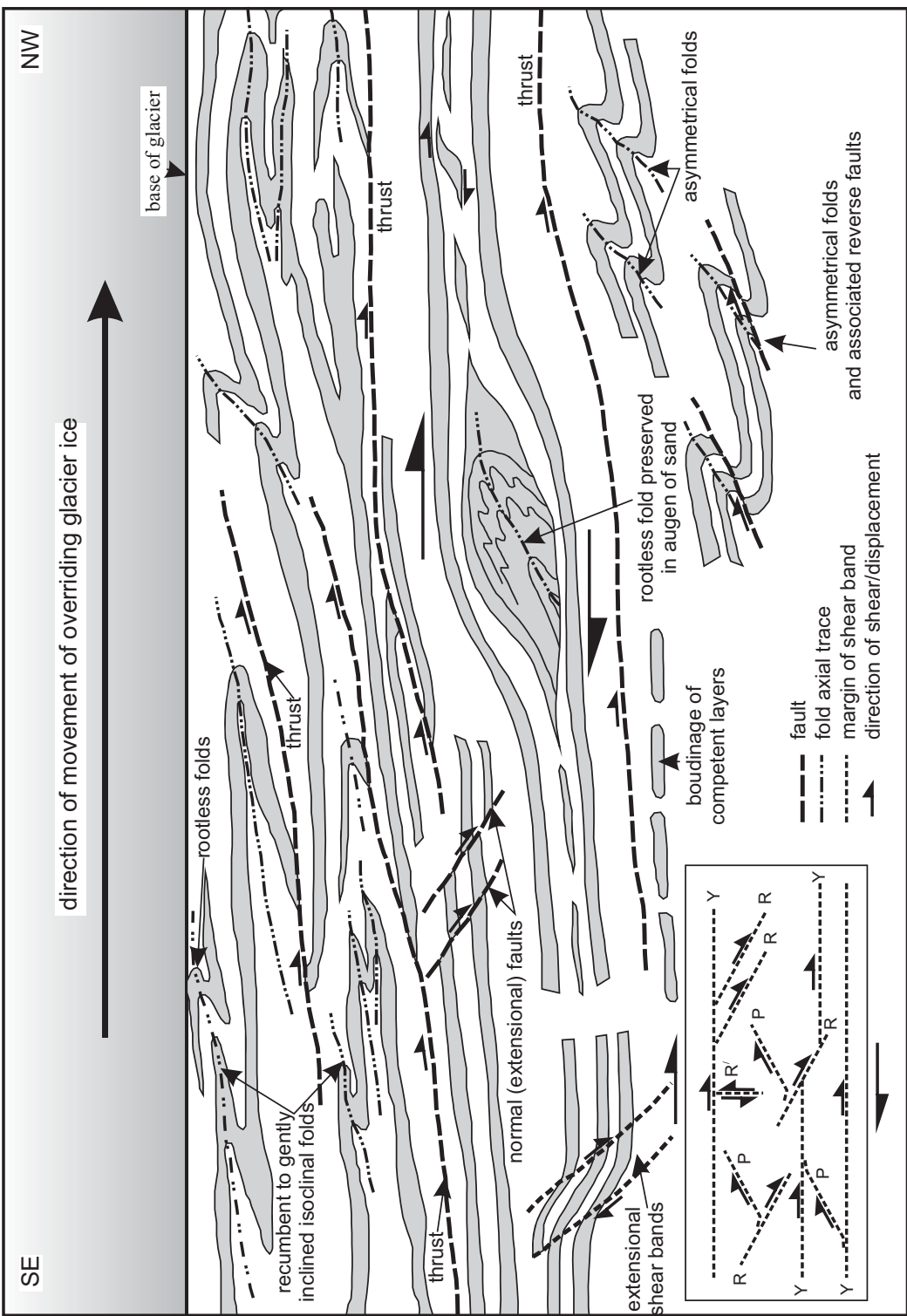


